\title{
Підвищення надійності елементів системи «водій-машина-дорожні умови» при експлуатації шарнірно-зчленованих машин
}

\author{
Є.О. Дубінін ${ }^{1}$, Д.М. Клец ${ }^{2}$, О.С. Полянський ${ }^{3}$ \\ 1, 2, 3 Харківський національний автомобільно-дорожній університет

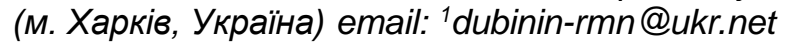

\begin{abstract}
Обґрунтований підхід до підвищення надійності системи «водій-машина-дорожні умови» при експлуатації шарнірно-зчленованих машин, що поліпшує взаємодію водія із системою забезпечення динамічної стійкості під час руху. Розроблений метод оцінювання надійності водія шарнірнозчленованої колісної машини з використанням у якості діагностичного параметра критерію дина-

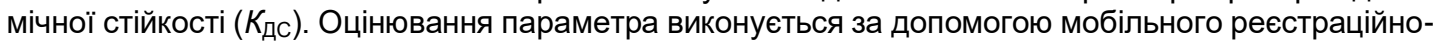
вимірювального комплекса.

Обгрунтування зон припустимих і неприпустимих значень критерію дозволяє визначити ступінь впливу водія на виникнення аварійних ситуацій, пов'язаних з перекиданням. Виходячи 3 того, що у водіїв відношення й мотивація до виконання транспортних операцій з дотриманням вимог 3 безпеки можуть бути різними, основний ефект для підвищення надійності при застосуванні розробленого підходу може бути отриманий за рахунок порівняння результатів об'єктивного контролю процесу руху за допомогою мобільного реєстраційно-вимірювального комплексу (МРВК) для різних водіїв у різних дорожніх умовах. Тобто програмно задається «зелена зона» поточних параметрів стійкості положення. Водій під час руху, враховуючи власні можливості, дорожні умови, питання економії палива тощо, обирає безпечний, на його погляд, режим руху. МРВК у процесі руху, демонструючи в режимі реального часу поточну величину критерію динамічної стійкості, підказує водієві щодо правильності обраного режиму. У разі високої інтенсивності зростання Кдс, наприклад за значної швидкості руху, що не відповідає дорожнім умовам, водій не встигає втрутитися у процес стабілізації машини. Тому для забезпечення стійкості положення буде спрацьовувати

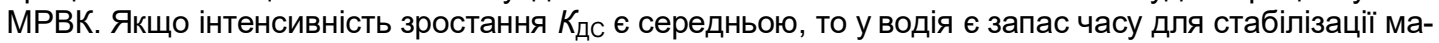
шини без підключення системи. Якщо ж інтенсивність зростання Кдс $є$ низькою, то водій повністю контролює процес руху, допомога МРВК у зазначеному випадку не потрібна.

На підставі проведених досліджень і аналізу існуючого досвіду розроблені додаткові рекомендації з підвищення безпеки використання колісних шарнірно-зчленованих машин з врахуванням їх конструктивних особливостей. Результати дослідження можуть бути використані при експлуатації шарнірно-зчленованих колісних машин.
\end{abstract}

Ключові слова: надійність, водій, стійкість положення, метод, параметр, шарнірнозчленований, критерій динамічної стійкості.

Вступ. Світова статистика свідчить, що в більшості ДТП винуватий водій [1]. Безпека руху багато в чому залежить від того, наскільки високий рівень професійної майстерності й транспортної культури водіїв, який визначає їх надійність як елемента системи «водій-машина-дорожні умови». Більша частина порушень (85\% та вище), що стали причиною ДТП, викликана прогалинами в навчанні водіїв, незнанням ними своїх професійних і психофізіологічних можливостей. Така ситуація вимагає більш детального вивчення процесу взаємодії водія та машини під час руху. Причому основним напрямком підвищення надійності водія під час експлуатації шарнірно-зчленованих машин $є$ створення відповідних систем та пристроїв, які б давали йому інформацію щодо параметрів стійкості в режимі реального часу у зручному для нього вигляді. Слід зазначити, що водій повинен бути навчений реагувати на сигнали таких систем та уникати аварійних ситуацій. В іншому випадку система повинна брати керування на себе та здійснювати необхідні дії щодо забезпечення стійкості положення машини. Тому в теперішній час питання підвищення надійності елементів системи «водіймашина-дорожні умови» при експлуатації шарнірно-зчленованих машин $є$ актуальними.

Аналіз останніх досягнень і публікацій. Дослідженню різних аспектів надійності водія присвячено роботи як вітчизняних, так і закордонних авторів [1-8]. Проведені дослідження в різних галузях [9], в тому числі в аграрному секторі України показали, що до найбільш значимих виробничих небезпек відносяться: порушення ПДР - 
13,3\%, недоліки під час навчання безпечним прийомам праці - 9,9\%, алкогольне й наркотичне сп'яніння - 8,9\%, порушення трудової та виробничої дисципліни - 8,7\%, порушення правил безпеки під час експлуатації машин - 5,1\%, незадовільні технічний стан і надійність машин - 16,8\%. Використання колісних машин з шарнірно-зчленованою рамою показує, що близько 85\% важких травм припадає на транспортні роботи, причому до 30\% з них зі смертельними випадками.

Мета и постановка завдань. Метою роботи є підвищення надійності системи «водій-машинадорожні умови» (ВМД) при експлуатації шарнірнозчленованих машин на основі застосування сучасного реєстраційно-вимірювального комплексу. Для досягнення поставленої мети необхідно вирішити наступні завдання: розробити метод оцінювання надійності водія шарнірно-зчленованої колісної машини з використанням у якості діагностичного параметра критерію динамічної стійкості; розробити рекомендації з підвищення безпеки використання колісних шарнірно-зчленованих машин 3 врахуванням їх конструктивних особливостей та використання сучасного мобільного реєстраційновимірювального комплексу (МРВК).

Підвищення надійності елементів системи «водій-машина-дорожні умови». Відомо, що найбільш серйозними помилками, що призводять до ДТП, є помилки оцінки ситуації (рис. 1) [1]. Тому для зниження ймовірності перекидання машини водієві необхідно мати своєчасну об'єктивну інформацію про її положення в просторі та умови її руху.

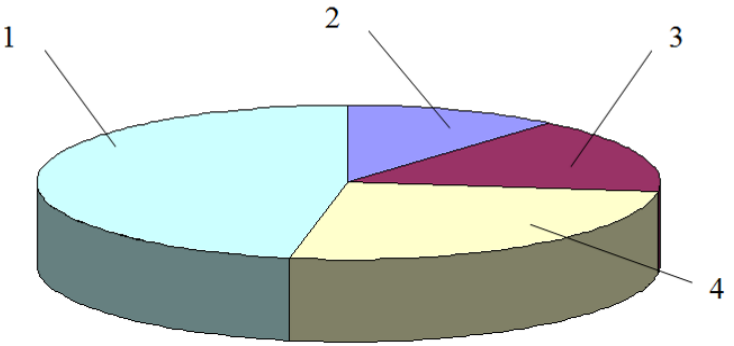

Рис. 1. Розподіл помилок водія в різних аварійних ситуаціях [1]

1 - помилки оцінки, 2 - помилки виконання дій, 3 - помилки прийняття рішень, 4 - помилки сприйняття

У роботі [2] встановлено, що часом реакції (запізнювання) людини називають проміжок часу між початком сигналу (стимулу) і завершенням реакції. Цей час складається із трьох складових часу на сприйняття сигналу, часу ухвалення рішення, часу здійснення дії. Перші два інтервали становлять моментальний (схований) період реакції, який триває десяті частки секунди. Час на здійснення дії залежить від його складності та від того, яка частина тіла робить дію. Цей час коливається від декількох сотих до десятих секунди. Цей час доцільно оцінювати за швидкістю руху руки або ноги й відстані до приладів. Середнє значення часу натискання кнопки без руху кисті близько 0,12 с, при повороті тулуба - 0,16 с. Елементарний рух руки в середньому займає 0,4-0,6 с. Загальний час простої реакції при винесенні руки до оптимально розташованих приладів звичайно займає 0,6-0,8 с при середньому квадратичному відхиленні 0,08 с [3].

Через індивідуальність людей час реакції $€$ випадковою величиною, що має асиметричний модальний розподіл. Крива розподілу звичайно має ліву гілку, що круто піднімається, і пологу праву гілку. При важких завданнях та незвичних зовнішніх умовах збільшується як середнє значення, так і дисперсія часу реакції, розподіл стає ще більш асиметричним (рис. 2). Збільшення інтенсивності сигналу скорочує час реакції, але до відомої межі. При величинах інтенсивності сигналу, що перевищують граничні, час вже не змінюється. Тривалість сигналу мало впливає на час реакції.

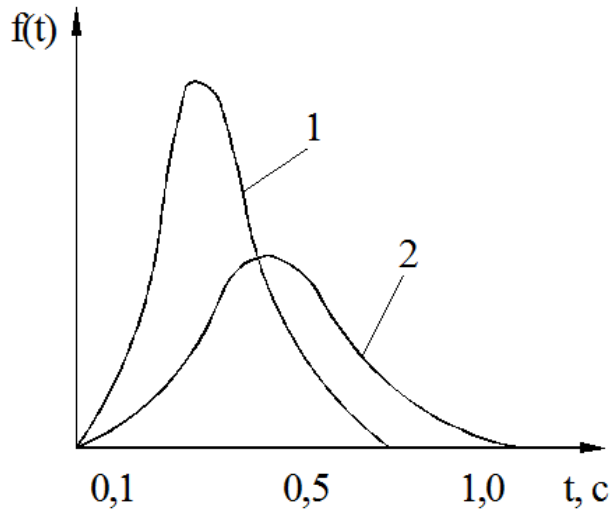

Рис. 2. Криві розподілу часу реакції [3] 1 - при простому завданні, сприятливих умовах роботи; 2 - при складному завданні, несприятливих умовах роботи

У дослідженнях [4] встановлено, що час реакції досвідченого водія, за результатами їх випробувань на комплексі, що моделює систему «водійавтомобіль-дорожні умови», лежав у межах 0,721,85 с із розподілом, близьким до нормального (середнє значення 1,24 с, коефіцієнт варіації 0,15). Для групи професіональних водіїв в якості статистичних характеристик часу реакції були прийняті фрункції розподілу трьох величин: $t_{\text {pmin }}$ і $t_{\text {pmax }}-$ мінімального та максимального $t_{p}$, обумовлених як середнє трьох відповідних екстремальних значень, $t_{p t}$ - часу реакції при гальмуванні. 
Функції розподілу цих величин (рис. 3) показують, що при аварійному гальмуванні час реакції змінюється в широких межах і з його крайніх значень різниця між $t_{p t}$ i $t_{p \min }$ виявляється більше, ніж між $t_{p t}$ i $t_{p \max }[4]$.

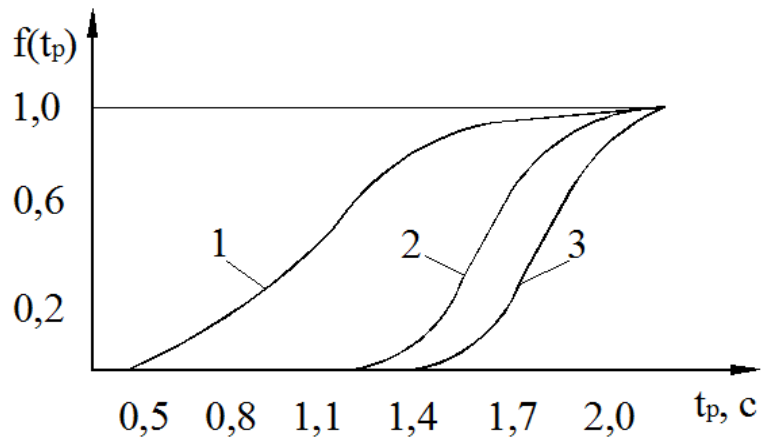

Рис. 3. Криві розподілу часу реакції водіїв за результатами їх випробувань на комплексі, що моделює систему ВМД [4] 1 - мінімальний час; 2 - час при аварійному гальмуванні; 3 - максимальний час

У дослідженнях [5] визначено, що середній оператор надійно переробляє інформацію й ухвалює оптимальні рішення з управління машиною, якщо потік інформації не перевищує 50 біт/с. При більшому потоці спрацьовує біологічний захисний механізм організму і його пропускна здатність зменшується, що різко погіршує якість контролю й керування машиною. Тому особливо важливо визначити раціональний об'єм інформації, що надається водієві, і вибрати найбільш вдалу форму відображення цієї інформації. Обидва завдання передбачають узгодження фрізіологічних можливостей людини з технічними потребами управління машиною в замкненій системі людина-машина.

У роботі [6] встановлено, що надійність функціонування багатьох систем залежить як від надійності апаратури, так і від надійності обслуговуючого персоналу. У системах людина-машина під помилкою людини мається на увазі вихід характеристик, що описують його функції, за припустимі межі, а під надійністю людини - імовірність відсутності помилок. Найпростішою моделлю таких систем $є$ каскадне з'єднання $m$ апаратурних підсистем і підсистеми оператора. Надійність оператора характеризується в таких моделях дискретними ймовірностями, обумовленими відношенням кількості успішних випробувань до загальної кількості випробувань.

Однією з основних відмінностей у властивостях надійності людини й машини $є$ те, що надійність машини розглядається до першого ушкодження, а помилки людини можуть випадковим чином повторюватися [7]. По-перше, на відміну від апаратури, людина безперервно вдоскона- лює свої характеристики шляхом навчання. Людина, як система, виконує певне завдання при впливі спостережуваного вхідного сигналу й має кінцеве число параметрів, що підлягають оцінці, які нелінійним чином залежать від напруження (при помірному напруженні характеристики найкращі). Ці характеристики можуть залежати від попередніх станів і визначаються умовами роботи, фрізичним, емоційним станом і так далі.

Також у дослідженнях [8] вказувалося, що надійність людини визначається як імовірність того, що завдання буде успішно виконане в межах необхідного мінімального часу. Під помилкою людини розуміється відмова від виконання запропонованого завдання або виконання забороненої дії, у результаті чого може бути ушкоджене устаткування або порушений встановлений графік операції. Розглядається наступна класифікація помилок людини: 1 - помилка технічного обслуговування; 2 - помилка виготовлення; 3 - помилка конструювання; 4 - помилка оператора; 5 - помилка інспектування; 6 - супутня помилка; 7 - помилка маніпуляції. Причинами помилок людини можуть бути неправильне технічне обслуговування устаткування, погані умови праці й інструменти, низька кваліфікація персоналу, та інші.

Під надійністю водія слід розуміти, за аналогією з технічними системами, його здатність протягом певного проміжку часу працювати без ДТП [1]. На основі проведеного аналізу підходів до оцінки впливу водія на процес руху машини можна виділити основні фактори, що впливають на безпеку такого руху щодо специфріки експлуатації шарнірно-зчленованих машин:

- кваліфікація водія (стаж водіння загальний, стаж водіння шарнірно-зчленованих машин, проходження занять з практики водіння шарнірнозчленованих машин, знання й уміння застосовувати прийоми керування шарнірно-зчленованими машинами в аварійних ситуаціях);

- стан водія (втома, хворобливий стан, загальний стан здоров'я ( у тому числі вікові зміни), морально-психологічний стан, алкогольне або наркотичне сп'яніння);

- психофізіологічні особливості водія (швидкість реакції, пам'ять, моральні якості і так далі).

Усі перераховані фрактори мають різну вагомість, їх внесок у забезпечення стійкості положення машини при русі різний і може змінюватися в часі випадковим чином. Тому диференціація кожного з фракторів являє собою складне завдання. Для розв'язку проблеми оцінювання впливу надійності водія необхідно знаходити нові підходи.

У цей час основним параметром, що характеризує надійність водія як елемента системи ВМД $€$ час реакції при аварійній ситуації. Вимір такого параметра сполучений з певними труднощами та вимагає наявності як спеціальної апаратури, так і 
спеціальної підготовки самого водія. Розроблений МРВК $[10,11]$, адаптований для оцінювання стійкості положення, дозволяє оцінити та підвищити надійність водія під час виконання технологічних операцій у процесі експлуатації. Основний підхід полягає в оцінюванні поточних параметрів стійкості положення як у режимі реального часу, так і під час аналізу зібраних масивів інформації (рис. 4) $[12,13]$. Иого застосування дозволить оцінити вплив водія як елемента системи ВМД на безпеку використання колісної машини за різних умов.

Виходячи з того, що у водіїв відношення й мотивація до виконання транспортних операцій 3 дотриманням вимог з безпеки можуть бути різними, основний ефект для підвищення надійності при застосуванні розробленого підходу може бути отриманий за рахунок порівняння результатів об'єктивного контролю процесу руху за допомогою МРВК для різних водіїв у різних дорожніх умовах. Тобто в комплексі програмно задається «зелена зона» поточних параметрів стійкості положення. Водій під час руху, враховуючи власні можливості, дорожні умови, питання економії палива тощо, обирає безпечний, на його погляд, режим руху. МРВК у процесі руху, демонструючи в режимі реального часу поточну величину критерію динамічної стійкості, підказує водієві щодо правильності обраного режиму.

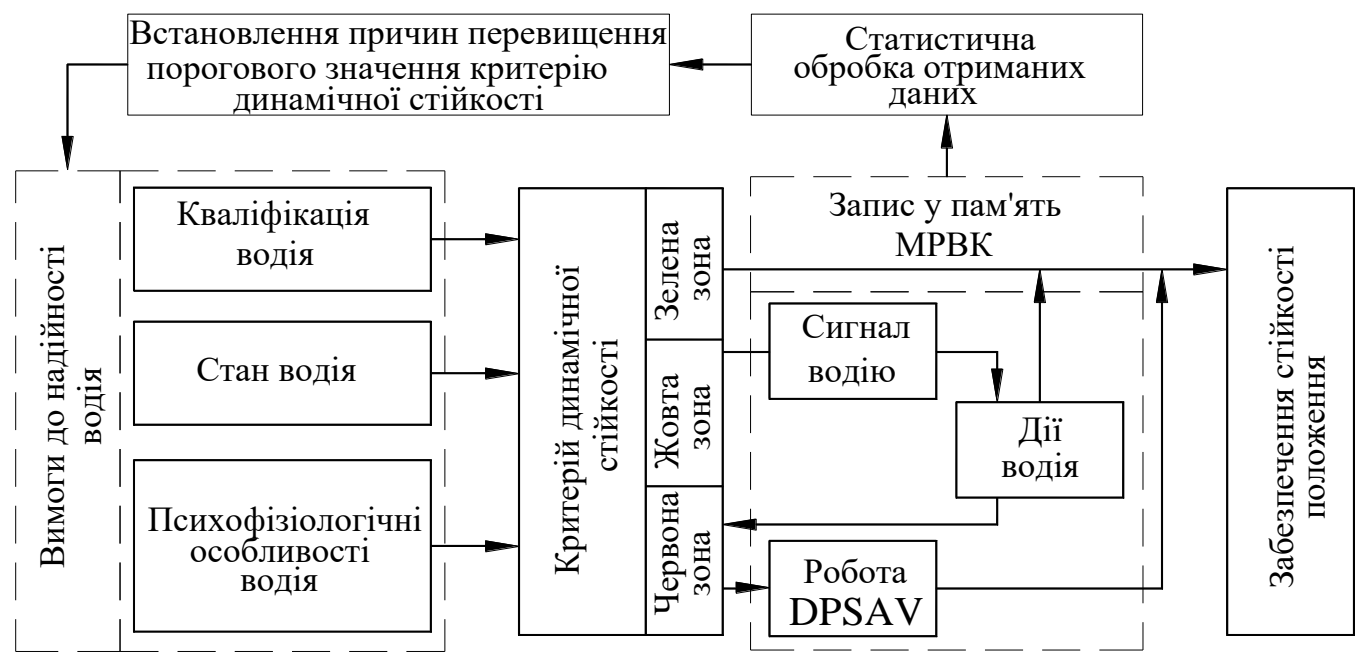

Рис. 4. Схема оцінки надійності водія як елемента системи ВМД

За параметр стійкості пропонується використання критерію динамічної стійкості $K_{\text {дс }}$, що визначається за залежністю (1)

$$
K_{\text {дс }}=\frac{\omega_{\text {поточн }}}{\omega_{\text {гран }}}
$$

де $\omega_{\text {поточн }}-$ поточне значення кутової швидкості колісної машини (секції) в поперечній вертикальній площині; $\omega_{\text {гран }}$ - гранична за умовою перекидання кутова швидкість колісної машини (секції) в поперечній вертикальній площині.

За $K_{\text {дс }}<1$ стійкість положення забезпечується, за досягнення $K_{\text {дс }} \geq 1$ існує небезпека перекидання.

У разі перевищення граничного значення «зеленої зони» система входить у режим «жовтої зони» (становить 65\% від максимального значення коефіцієнта динамічної стійкості). У цьому випадку водій одержує світловий і звуковий сигнали. За незадовільної реакції водія або ігноруванні сигналу система входить у режим «черво- ної зони» (становить 80\% від максимального коефріцієнта динамічної стійкості). Зважаючи на подальшу незадовільну реакцію водія або ігнорування сигналу, система буде давати команду на зниження подачі палива включно до зупинки машини. Всі виходи контрольованого параметра за межі зон записуються в пам'ять МРВК і аналізуються в подальшому для визначення ступеня впливу водія на безпеку використання колісної машини. Граничні значення зон обрані з урахуванням існуючих наробітків з встановлення критерію бічної стійкості [14] і часу реакції водія [4].

Зонування Кдс під час взаємодії водія з системою з урахуванням його часу реакції $t_{p}$ на аварійну ситуацію представлено на рисунку 5 [12].

У разі високої інтенсивності зростання Кдс1, наприклад за значної швидкості руху, що не відповідає дорожнім умовам, водій не встигає втрутитися у процес стабілізації машини. Тому для забезпечення стійкості положення буде спрацьовувати МРВК. Якщо інтенсивність зростання Кдс2 $€$ 
середньою, то у водія є запас часу для стабілізації машини без підключення системи. Якщо ж інтенсивність зростання Кдсз $є$ низькою, то водій повністю контролює процес руху, допомога МРВК у зазначеному випадку не потрібна.

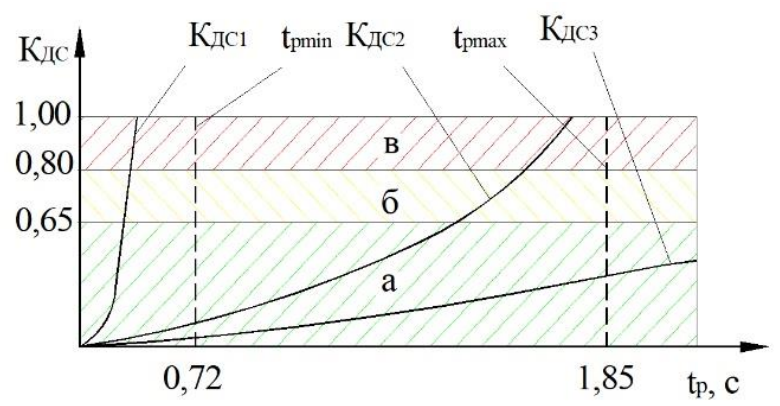

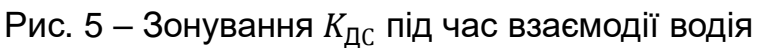
з системою забезпечення динамічної стійкості положення за складної задачі, несприятливих умов роботи а - «зелена зона»; б - «жовта зона»; в - «червона зона»

Статистична обробка результатів може дати повну картину на будь-якому проміжку часу експлуатації відносно виконання вимог щодо безпеки використання шарнірно-зчленованих машин як в одиничному випадку, так і у випадку використання парку машин. При частих виходах за «зелену зону», але відсутності спрацьовування МРВК виникають питання про організацію процесу перевезень (маршрут, дорожні умови і так далі). При багаторазовому виході параметра в «червону зону» виникають питання щодо надійності даного водія як елемента системи ВМД. При цьому надалі можливі профілактичні заходи з водіями, з'ясування конкретних причин таких ситуацій, матеріальне мотивування до виконання інструкцій.

У роботі [15] пропонуються до використання в реальній експлуатації правила, що дозволяють забезпечити стійкість трактора із причепом при виконанні робіт. Ці правила можуть бути доповнені з урахуванням специфіки конструкції та робіт, що виконуються машиною, а також результатів аналізу випадків перекидання. Так, вимагається наявність гальм у причепа (керованих з робочого місця водія, автоматичних для запобігання аварій і ручних). Також двохосьові причепи повинні мати пристрої, що дозволяють загальмувати причіп на стоянці. Усі причепи до тракторів повинні мати жорсткі зчепи, що не дозволяють їм накочуватися на трактор. Рух накатом, особливо при спусках, повинний бути заборонений. Не рекомендується знаходження поруч із водієм пасажира, тому що це може утруднювати керування трактором. Під час руху з одноосьовими причепами рекомендується проводити відповідне баластування осей трактора.
Були розроблені відповідні рекомендації [15]: трактори допускаються до експлуатації тільки після перевірки механіком відповідних систем і пристроїв (підвіска й шини, гальмівна система, рульове керування, зчіпний пристрій); забороняється буксирування причепів і напівпричепів на поворотах, ухилах, за важких дорожніх умов зі швидкістю більше 10 км/год; забороняється буксирування навантажених причепів і напівпричепів без гальм на ухилах більше $10^{\circ}$ (при наявності повороту - більше $5^{\circ}$ ), зі швидкістю більше 12 км/год у нормальних дорожніх умовах (більше 5 км/год - за важких дорожніх умов); забороняються круті повороти, переїзд канав і валів з великим креном і швидкістю руху; до керування машиною допускаються водії, що вивчили особливості роботи трактора, що впливають на його стійкість положення, характер місцевості й доріг, якими планується здійснювати рух.

У роботі [16] також зазначена необхідність суворого виконання правил експлуатації колісних тракторів в умовах руху на ухилах. Так, у господарствах необхідне проведення паспортизації земельних ділянок із вказівкою крутизни поздовжніх і поперечних ухилів, перешкод, небезпечних місць і іншого. До керування тракторами, які працюють на ухилах, допускають трактористів не нижче II класу зі стажем роботи за спеціальністю не менше 3 років, які пройшли спеціальне навчання й інструктажі з техніки безпеки при виконанні робіт у відповідних умовах. Тракторист зобов'язаний оглянути й вивчити особливості майбутнього маршруту руху.

На підставі проведених досліджень і аналізу існуючого досвіду розроблені додаткові рекомендації з підвищення безпеки використання колісних шарнірно-зчленованих машин з врахуванням їх конструктивних особливостей:

- до керування допускаються водії, що одержали спеціальні навички в процесі тренувань на шарнірно-зчленованих тракторах (інший підхід до повороту, маневреність, характеристики підвіски і так далі);

- до роботи на ухилах і в умовах пересіченої місцевості допускаються водії зі стажем безаварійної роботи на шарнірно-зчленованих машинах не менше 3 років;

- на спусках повинен бути включений повний привід, не допускається різке обертання керма;

- на схилах забороняється виконувати повороти (розвороти) зі складанням в бік зниження;

- водій повинен мати навички використання приладу контролю граничних кутів перекидання та системи контролю динамічної стійкості трактора;

- необхідне обмеження руху за важких дорожніх умов у темний час доби, на ухилах та в умовах пересіченої місцевості - заборона руху;
Інженерія природокористування, 2020, №1(15), с. 109 - 116

Engineering of nature management, 2020, \#1(15), p. 109 - 116 
- при влученні колеса (коліс) одного борту в яму або канаву необхідно обертати кермо в бік провалених коліс при максимально можливому сповільненні в даних умовах до повної зупинки (у цьому випадку центри мас секцій обертаються в бік, протилежний проваленим колесам, створюючи додаткові стабілізуючі моменти, а також центри мас переміщуються на більшу відстань від осі перекидання).

\section{Висновки}

1. Розроблений метод оцінювання надійності водія шарнірно-зчленованої колісної машини 3 використанням у якості діагностичного параметра критерію динамічної стійкості Кдс, $з$ врахуванням зон припустимих і неприпустимих станів. Зонування критерію дозволяє визначити ступінь впливу водія на виникнення аварійних ситуацій, пов'язаних з перекиданням. Розроблені підходи, що поліпшують взаємодію водія із системою забезпечення динамічної стійкості під час руху.

2. На підставі проведених досліджень і аналізу існуючого досвіду розроблені додаткові рекомендації з підвищення безпеки використання колісних шарнірно-зчленованих машин з врахуванням їх конструктивних особливостей.

\section{Література}

1. Венгеров И. А. Актуальные вопросы безопасности дорожного движения (повышение профессиональной надежности водителей) / И.А. Венгеров, А. А. Пинт. - М.: Знание, 1987. - 64 с.

2. Дружинин Г. В. Анализ эрготехнических систем / Дружинин Г.В.- М.: Энергоатомиздат, 1984. - $160 \mathrm{c}$.

3. Ломов Б. Ф. Военная инженерная психология / [Ломо Б. Ф., Васильев А. А., Офицеров В. В., Рубахин В. Ф.]; под. ред. Б. Ф. Ломова. - М.: Воениздат, 1970. -400 с.

4. Ротенберг Р. В. Основы надежности системы водитель-автомобиль-дорога-среда / Ротенберг Р. В. - М.: Машиностроение, 1986. -216 с.

5. Инженерная психология в применении к проектированию оборудования. Пер. с англ. под. ред. Б. Ф. Ломова, В. И. Петрова. - М.: Машиностроение, 1971. - 619 с.

6. Park K. S. Human reliability with probabilistic learning in discrete and continuons tasks: conceptualization and modeling / K. S. Park // Microelectronics Reliability. - 1985. - Vol. 25, № 1. - pp. 157 - 166.

7. Хассан М. М. Разработка методов и средств защиты агрегатов шасси трактора от перегрузов с использованием человека-оператора: дисс. ... канд. техн. наук: 05.20.01 / Мурад Хассан Мохамед. - Х., 1988. - 173 с.

8. Dhillan B. S. Stohastic models for evaluating probability of system failure due to human error / B. S. Dhillan // Microelectronics Reliability. - 1984. Vol. 24, № 5. - pp. 921 - 924.
9. Подобєд І. М. Прогнозування виробничого травматизму в аграрному секторі економіки України: автореф. дис. ... канд. техн. наук: 05.26.01 / Подобєд Іван Мефодійович. - К., 2008. - 20 с.

10. Дубинин Е.А. Повышение надежности колесных машин совершенствованием интеллектуальных бортовых систем / Дубинин Е.А., Клец Д.М., Полянский А.С., Холодов А.П. // Вісник ХНТУСГ. - Х. : ХНТУСГ. - 2019. - Вип. 205.- с. 39 - 48.

11. Клец Д.М. Мобільний реєстраційновимірювальний комплекс як основа інтелектуальної платформи підвищення безпеки експлуатації колісних машин / Клец Д.М., Дубінін Є.О., Холодов А.П., Слинченко І.В. // Сучасні енергетичні установки на транспорті, технології та обладнання для їх обслуговування СЕУТТОО-2019: 10 Міжнародна науково-практична конференція, Херсонська державна морська академія. - Херсон, 12-13 вересня 2019 р. - С. 203 - 205.

12. Дубинин Е. А. Фактор надежности водителя как элемента системы «водитель-машинадорожные условия» в обеспечении устойчивости положения колесной машины / Е. А. Дубинин // Технічний сервіс агропромислового, лісового та транспортного комплексів: науковий журнал. 2016. - № 5. - С. 64 - 69.

13. Дубинин Е. А. Метод оценки надежности водителя как элемента системы «водитель-машина-дорожные условия» / Е.А. Дубинин // Новітні технології в автомобілебудівництві та транспорті: міжнар. наук.-практ. конф., 15-16 жовтня 2015 р.: тези доп. - Х., 2015. - С. 205 - 208.

14. Электронные системы контроля устойчивости: ECE/TRANS/180/ Add.8. - [Введены в Глобальный регистр. 2008-06-26] - Женева: Глобальный регистр. Организация объединённых наций, 2008. - 116 с.

15. Поспелов Ю. А. Устойчивость трактора / Поспелов Ю. А. - М.: Машиностроение, 1966. -248 c.

16. Бутко Д. А. Безпека технологічних процесів при виробництві та післязбиральній обробці продукції рослинництва: навчальний посібник / [Бутко Д. А., Лущенков В. Л., Рогач Ю. П., Петров В.В.]. - Сімферополь: Бізнес-Інформ, 2002. $344 \mathrm{c}$.

\section{Reference}

1. Vengerov I.A. Aktualnye voprosy bezopasnosti dorozhnogo dvizheniya (povyshenie professionalnoj nadezhnosti voditelej) / I. A. Vengerov, A. A. Pint. - M.: Znanie, 1987. - 64 s.

2. Druzhinin G. V. Analiz ergotehnicheskih sistem / Druzhinin G. V. - M.: Energoatomizdat, 1984. $-160 \mathrm{~s}$.

3. Lomov B. F. Voennaya inzhenernaya psihologiya / [Lomov B. F., Vasilev A. A., Oficerov V. V., Rubahin V. F.]; pod. red. B. F. Lomova. - M.: Voenizdat, 1970. $-400 \mathrm{~s}$. 
4. Rotenberg R. V. Osnovy nadezhnosti sistemy voditel-avtomobil-doroga-sreda / Rotenberg $R$. V. - M.: Mashinostroenie, 1986. $-216 \mathrm{~s}$.

5. Inzhenernaya psihologiya $v$ primenenii $k$ proektirovaniyu oborudovaniya. Per. s angl. pod. red. B. F. Lomova, V. I. Petrova. - M.: Mashinostroenie, 1971. $-619 \mathrm{~s}$.

6. Park K. S. Human reliability with probabilistic learning in discrete and continuons tasks: conceptualization and modeling / K. S. Park // Microelectronics Reliability. - 1985. - Vol. 25, № 1. - pp. 157-166.

7. Hassan M. M. Razrabotka metodov i sredstv zashity agregatov shassi traktora ot peregruzov $\mathrm{s}$ ispolzovaniem cheloveka-operatora: diss. ... kand. tehn. nauk: 05.20.01 / Murad Hassan Mohamed. H., 1988. $-173 \mathrm{~s}$.

8. Dhillan B. S. Stohastic models for evaluating probability of system failure due to human error / B. S. Dhillan // Microelectronics Reliability. - 1984. Vol. 24, № 5. - pp. 921 - 924.

9. Podobied I.M. Prohnozuvannia vyrobnychoho travmatyzmu $v$ ahrarnomu sektori ekonomiky Ukrainy: avtoref. dys. ... kand. tekhn. nauk: 05.26.01 / Podobied Ivan Mefodiiovych. - K., 2008. - 20 s.

10. Dubinin Ye.A. Povyshenie nadezhnosti kolesnyh mashin sovershenstvovaniem intellektualnyh bortovyh sistem / Dubinin E.A., Klets D.M., Polyanskij A.S., Holodov A.P. // Visnik HNTUSG.H.:HNTUSG.-2019.-Vip. 205.-s. 39 - 48.

11. Klets D.M. Mobilnyi reiestratsiino-vymiriuvalnyi kompleks yak osnova intelektualnoi platformy pidvyshchennia bezpeky ekspluatatsii kolisnykh mashyn / Klets D.M., Dubinin Ye.O., Kholodov A.P., Slynchenko I.V. // Suchasni enerhetychni ustanovky na transporti, tekhnolohii ta obladnannia dlia yikh obsluhovuvannia SEUTTOO2019: 10 Mizhnarodna naukovo-praktychna konferentsiia, Khersonska derzhavna morska akademiia. Kherson, 12-13 veresnia 2019 r. - S. 203 - 205.

12. Dubinin E. A. Faktor nadezhnosti voditelya kak elementa sistemy «voditel-mashina-dorozhnye usloviya» v obespechenii ustojchivosti polozheniya kolesnoj mashiny / E. A. Dubinin // Tehnichnij servis agropromislovogo, lisovogo ta transportnogo kompleksiv: naukovij zhurnal. -2016. - № 5. - S. 64 - 69.

13. Dubinin E. A. Metod ocenki nadezhnosti voditelya kak elementa sistemy "voditel-mashinadorozhnye usloviya» / E. A. Dubinin // Novitni tehnologiyi $v$ avtomobilebudivnictvi ta transporti: mizhnar. nauk.-prakt. konf., 15-16 zhovtnya 2015 r.: tezi dop. - H., 2015. - S. 205 - 208.

14. Elektronnye sistemy kontrolya ustojchivosti: ECE/TRANS/180/ Add.8. - [Vvedeny v Globalnyj registr. 2008-06-26] - Zheneva: Globalnyj registr. Organizaciya obedinyonnyh nacij, 2008. - $116 \mathrm{~s}$.

15. Pospelov Yu. A. Ustojchivost traktora / Pospelov Yu. A. - M.: Mashinostroenie, 1966. - $248 \mathrm{~s}$.

16. Butko D.A. Bezpeka tekhnolohichnykh protsesiv pry vyrobnytstvi ta pisliazbyralnii obrobtsi produktsii roslynnytstva: navchalnyi posibnyk / [Butko D.A., Lushchenkov V.L., Rohach Yu.P., Petrov V.V.]. - Simferopol: Biznes-Inform, 2002. - 344 s.

\title{
Аннотация
}

\section{Повышение надежности элементов системы «водитель-машина-дорожные условия» при эксплуатации шарнирно-сочлененных машин}

\author{
Е.А. Дубинин, Д.М. Клец, А.С. Полянский
}

Обоснован подход к повышению надежности системы «водитель-машина-дорожные условия» при эксплуатации шарнирно-сочлененных машин, что улучшает взаимодействие водителя с системой обеспечения динамической устойчивости во время движения. Разработан метод оценивания надежности водителя шарнирно-сочлененной колесной машины с использованием в качестве диагностического параметра критерия динамической устойчивости (КДУ). Оценивание параметра выполняется с помощью мобильного регистрационно-измерительного комплекса.

Обоснование зон допустимых и недопустимых значений критерия позволяет определить степень влияния водителя на возникновение аварийных ситуаций, связанных с опрокидыванием. Исходя из того, что у водителей отношение и мотивация к выполнению транспортных операций с соблюдением требований по безопасности могут быть разными, основной эффект для повышения надежности при применении разработанного подхода может быть получен за счет сравнения результатов объективного контроля процесса движения с помощью мобильного регистрационно-измерительного комплекса (МРИК) для разных водителей в разных дорожных условиях. То есть программно задается «зеленая зона» текущих параметров устойчивости положения. Водитель во время движения, учитывая собственные возможности, дорожные условия, вопросы экономии топлива и тому подобное, выбирает безопасный, на его взгляд, режим движения. МРИК в процессе движения, демонстрируя в режиме реального времени текущую величину критерия динамической устойчивости, подсказывает водителю относительно правильности избранного режима. В случае высокой интенсивности роста КДУ, например при значительной скорости движения, которая не отвечает дорожным условиям, водитель не успевает вмешаться в процесс стабилизации машины. 
Поэтому для обеспечения устойчивости положения будет срабатывать МРИК. Если интенсивность роста КДУ является средней, то у водителя есть запас времени для стабилизации машины без подключения системы. Если же интенсивность роста КДУ является низкой, то водитель полностью контролирует процесс движения, помощь МРИК в отмеченном случае не нужна.

На основании проведенных исследований и анализа существующего опыта разработаны дополнительные рекомендации по повышению безопасности использования колесных шарнирно-сочлененных машин с учетом их конструктивных особенностей. Результаты исследования могут быть использованы при эксплуатации шарнирно-сочлененных колесных машин.

Ключевые слова: надежность, водитель, устойчивость положения, метод, параметр, шарнирно-сочлененный, критерий динамической устойчивости.

Abstract

\section{Improving the reliability elements of the "driver-machine-road conditions" system with the operation of the articulated vehicles}

\section{Ye.A. Dubinin, D.M. Klets, A.S. Polianskyi}

The approach to improving the reliability of the "driver-vehicle-road conditions" system in the operation of articulated vehicles is justified, which improves the driver's interaction with the system of ensuring dynamic stability during driving. The method of assessing the reliability of the driver of articulated wheeled vehicle has been developed, using the Dynamic Stability Criterion (DSC) as a diagnostic parameter. The parameter is evaluated using a mobile registration and measurement complex (MRMC).

The justification of the zones of acceptable and unacceptable values of the criterion allows to determine the degree of influence of the driver on the occurrence of accidents related to rollover. Based on the fact that drivers' attitude and motivation to perform transport operations with compliance with safety requirements may be different, the main effect for improving reliability in the application of the developed approach can be obtained by comparing the results of objective control of the process of movement with the help of MRMC for different drivers in different road conditions. The "green zone" of the current position stability parameters is set. The driver during driving, taking into account his own capabilities, road conditions, fuel economy and other parameters, chooses a safe, in his opinion, mode of movement. MRMC in the process of movement, demonstrating in real time the current value of the criterion of dynamic stability, tells the driver about the correctness of the chosen mode. In the case of high growth intensity of the DSC, for example, at a significant speed of movement, which does not meet the road conditions, the driver does not have time to intervene in the process of the vehicle stabilization.

Therefore, MRMC will be triggered to ensure sustainability. If the growth rate of the DSC is not critical, then the driver has a reserve of time to stabilize the vehicle without connecting the system. If the growth intensity of the DSC is low, the driver is in full control of the process of movement, the help of MRMC in the marked case is not needed.

Based on the research and analysis of existing experience, additional recommendations have been developed to improve the safety of the use of articulated wheeled vehicles, taking into account their design features. The study results can be used in the operation of articulated wheeled vehicles.

Keywords: reliability, driver, position stability, method, parameter, articulated, dynamic stability criterion.

\section{Бібліографічне посилання/ Bibliography citation: Harvard}

Dubinin, Y. A., Klets, D. M. and Polianskyi, A. S. (2020) Improving the reliability elements of the 'driver-machine-road conditions' system with the operation of the articulated vehicles. Engineering of nature management, (1(15), pp. 109 - 116.

Подано до редакції / Received: 11.01.2020 